\title{
Commercialised occupation skills: Israeli security experience as an international brand
}

\author{
Erella Grassiani
}

\begin{abstract}
I SRAELI SECURITY PERSONNEL, technology, and ideas are immensely popular in places around the world that are perceived or marked as insecure. The fact that an idea, strategy, person, or technology comes from this small country in the Middle East seems to be enough for people and states to blindly believe its effectiveness. At the heart of this conviction is the Israeli experience in conflict, urban warfare, and dealing with terrorism. As an American journalist wrote: 'everybody's favourite soldier of fortune is an Israeli with military experience' (Johnson 2010: n.p.). To illustrate this phenomenon, I will start with an example. A security company owned by an Israeli in the United States (US) was asked to set up security checkpoints in New Orleans after hurricane Katrina struck in 2005. The location where they performed this task was Audubon Place, which is a private, rich enclave. When hurricane Katrina hit, the inhabitants were afraid that criminals roaming the city's streets would rob their homes and they decided to hire this private security company (PSC) the operatives of which (Israeli ex-combatants) were helicoptered into Audubon Place by the American private military firm Blackwater, dressed in bulletproof vests and carrying M-16 automatic rifles. Interestingly, the inhabitants had specifically asked for Israeli security personnel. The operatives manned the gates of the enclave and made sure that no one entered. When interviewed by a journalist the Israeli ex-combatants said they had 'been fighting the Palestinians all day, every day, our whole lives', emphasising that the mere look of their gun would scare away criminals, making this job a piece of cake in comparison (Scahill 2005: n.p.). The Israeli founder of the company furthermore stated that '[his] people were highly trained to operate in hostile environments. That fit well with the demand of the situation in New Orleans' (Hutchinson and Masson 2007: n.p.), clearly making reference to their background in the Israeli Defence Forces (IDF).
\end{abstract}


This example illustrates the existence of a connection between Israel, a presumed security expertise, and a keen international market that makes the movement of such notions possible. It also fits neatly into the following description of the workings of the Israeli homeland security industry: "[it] sells its products and services by maintaining that Israel has experienced the horror not virtually, but first hand - and consequently both knows how to deal with such horror and has developed the appropriate instruments to do so' (Gordon 2009: 3). 'The horror' refers here to terror attacks and other threats to Israel and its citizens. In order to understand this commercial, mobile aspect of the security/military industrial complex, I examine the ways in which what I call the 'Israeli security experience' (ISE) is exported and branded internationally by distributing it to other countries and thus making it mobile. I conceptualise this as 'security capital' and use this concept as an analytical tool to understand these processes.

At the heart of the increasing popularity of PSCs in general are perceptions of increasing risk, insecurity, and fear. Not only in the US, but also in Europe people are becoming increasingly afraid of possible terror attacks, 'the Muslim', the strange other, and the collapse of their familiar and comfortable lives. States and their policymakers speak about 'security' as something we always need more of and citizens start looking for ways to 'protect' themselves, to regain a feeling of safety. Security has been on states' minds since their early formation (Goldstein 2010), but if we look at states' subjects we see that especially after 9/11, and continuing today with foreign (European) 'fighters' joining the Islamic State in Syria and Iraq, a so-called culture of fear (Furedi 2002; 2006) becomes visible. Jeff Sluka has even called this a 'terror of terrorism' and a 'paranoid fear of terrorism'. ${ }^{1}$

These preoccupations with (in)security reverberate not only in the way our feelings are constructed, but we are also made to feel responsible for our own security within a neoliberal notion of 'responsiblization' (Goldstein 2010: 492). In the world that Frank Furedi (2006: 3) describes, 'virtually every institution bars, universities, doctors' surgeries, sport, public transportation - takes security very seriously. Burglar alarms, outdoor lights, panic buttons, CCTV cameras and an array of private security personnel are testimony to a flourishing market in fear'. Citizens become customers and (in)security has become a commodity, something we can buy and sell on a global market. The products or commodities that we can find in such markets are then products of our perceptions of fear, often propagated by the state (such as the discourse on the war on terror by the Bush administration). Thus, "[a] "culture of fear" has taken root in Western cultures, promoted by state institutions and exacerbated by those working within the media and security industries' (Mythen and Walklate 2006: 126). (In)security, in the words of Mark Neocleous (2007), becomes a fetish, a commodity which we cannot get enough of. 
Here I explore the way specific PSCs that operate internationally brand themselves through the use of the Israeli combat and security experience of their founders and/or employees and through other links to Israel as a nationin-arms. ${ }^{2}$ Specific ideas about 'Israeli-ness' and subsequent notions of security thus become mobile globally and find their way into different (national) contexts. The assumption that being Israeli or having an Israeli connection means good security is interesting as it shows how 'knowing about' (in)security is something that can be accumulated and exported elsewhere and sold on the free market. I argue that 'Israeli-ness' in the form of ISE can be analysed as security capital. By using this concept we can trace how specific abilities and other forms of capital can offer security companies or consultants more standing and legitimacy within the world of security. Using this term can lead to insights into the broader processes of the global security/industrial complex connecting Israel with other places around the world and show how specific experiences and knowledge, but also materials, can be used to gain symbolic capital (Bourdieu 2002).

After discussing the ways in which we can analyse security and security experience as a commodity and brand, I discuss the specific case of Israeli security and explore the security capital as part of the ISE brand these security companies utilise abroad. This article is based on fieldwork in Israel and Kenya on the Israeli security industry and on the analysis of websites of PSCs that are founded by Israelis abroad.

\section{Security for sale}

My approach towards the concept of security is a critical, anthropological one, as proposed by Daniel Goldstein (2010). His approach takes us away from the idea of security as a public good that is (ideally) available for all, towards conceptualising security through the meaning it has for people who supposedly are (in)secure or, as in this case, through the way it is used by sellers of 'security' as a commodity. While the Copenhagen school emphasised security, or rather securitisation, as intersubjective and performative, thus taking us away from looking at security in terms of what is a real threat or not (Buzan et al. 1998), it is still very state-centred (Goldstein 2010). A more anthropological, critical approach to security 'can explore the multiple ways in which security is configured and deployed - not only by states and authorized speakers but by communities, groups, and individuals - in their engagements with other local actors and with arms of the state itself' (Goldstein 2010: 492). I explore this idea in the private, profit-making sector by focusing on security companies and the mobility of their products and ideas.

When looking at the ways the concept of security is used in order to sell a specific good, we need to consider what kind of good it is. Should we conceptualise security as a collective good, ideally available to all, or as a private good, 
available to those who pay for it (Krahmann 2008)? A collective or public good is characterised as 'non-excludable and non-rival in consumption' (Krahmann 2008: 383). It seems that in order to understand the growing private security market, security should be seen in the way it is conceptualised within this market, which is clearly as a private good one can buy and sell, even though it is often framed as serving the wider public.

This public increasingly internalises the perception of security as a private good. Ian Loader (1999: 381) reminds us that the "assessments that individuals make of how "at risk" they are and what levels of protection they "need" are not precise, actuarial calculations ... but social and cognitive constructs assembled from a mix of experience, local rumour and storytelling, and mass-mediated imagery and information'. Part of this mix that provides ideas about risks for the public and about what security measures should be taken are PSCs themselves, who have become 'security experts' who not only provide security tools but also security knowledge (Leander 2005: 612). Thus, as Neocleous (2007) convincingly argues, the need for security does not come from an objective outside force, but is produced by the same security industry that sells it.

While security has often been analysed through the lens of consumerism, or the consumer culture that has been growing globally for decades (Loader 1999; Goold et al. 2010), I focus on the way security is branded by its producers, security 'specialists' and others on the sales side of the market. A product first has to become a commodity that has meaning for persons who are selling and/or buying it. For it to become a commodity, a product needs to go through a "process of "evaluation," of qualifying and requalifying ... [when] the qualities of a product are stabilized; the product becomes a "good" (Foster 2007: 713). This involves capital; once a good or idea is associated with specific values that are appreciated in society, the meaning and value they beget grows. These qualities and meanings are then bundled in a brand which has values and has an 'emotional dimension with which people can identify' (Van Ham 2001: 2), preferably by using few words but a strong message. It has been increasingly recognised that branding does not only apply to products, but also to places such as cities or whole countries (e.g., Kavaratzis and Ashworth 2005; Coaffee and Rogers 2008). A brand 'embodies a whole set of physical and socio-psychological attributes and beliefs which are associated with the product ... it is the forging of associations' (Kavaratzis and Ashworth 2005: 508).

Jon Coaffee and Peter van Ham (2008) show how security branding can be part of the way cities, neighbourhoods, or even states are marketed. They show how emphasising security measures in a place can add to the creation of unique selling points that strengthen a (city) brand. They thus view security as something that can strengthen a brand. However, I show that security and especially security experience and knowledge can be analysed as brands themselves, 
brands that help to sell specific knowledge and technology and that are strongly connected to a specific place.

Another point that is brought up by these authors is the way that entities such as North Atlantic Treaty Organization (NATO) or the European Union (EU) sell their goods by using their names as trustworthy brands. Through selling security goods with a 'made in [country]-label', the national character of security as a brand becomes clear (Coaffee and Van Ham 2008: 194). I use these ideas about branding, while extending them to include activities or experiences related to places; in this case combat and security experience that is intrinsically connected to 'Israeli-ness'. ISE is then labelled as 'made in Israel' (or 'Blue/ White' as is said in Israel, referring to the colours of the national flag), which provides security customers with a sense of buying something good, professional, and of high quality.

Thus it is important to think about the ways in which experience, in addition to security as a concept by itself, can become something that is used to sell or buy products and services on the market. In other words, when does a specific experience of an individual come to be regarded as capital in a Bourdieusian sense and beget value? In this case experience in the military and security industry is meaningful within Israeli society, as I explain shortly, and gives someone status. It is then exported elsewhere where this security experience becomes security capital in a non-Israeli context, and thus is made meaningful.

Joseph Pine and James Gilmore (1998) make a clear distinction between goods, commodities, services, and finally, experience as economic entities. However, from their perspective experience is something that a commercial agent can stage and offer people on the market, while I use experience as capital with which other services, goods, and commodities are sold on that market. Experience, in the way I analyse it, is thus not sold in a literal sense, but rather in the sense of the story, the history, and the unique selling point of a product. It is then important to look at 'the images that ... [PSCs] construct of themselves and the stories they tell about their products' (Joachim and Schneiker 2014: 247). These images and stories, in this case, consist of combat and security experience of security personnel connected to the PSCs. These are the narratives that give experience, products, and agents (security capital) their special value (symbolic capital) and finally their economic capital.

\section{Israel as a nation of security experts}

Israel's state and society are heavily influenced by the military, and it is important to firstly understand this connection to see the way it affects the international security industry of which Israel is part. Gabriel Sheffer and Oren Barak (2013) have drawn a distinction between different 'schools' in the research of socio-military relations and each school has a different approach when it comes 
to the militarisation of Israel. The traditionalists called it a 'nation-in-arms', the critics spoke more often of the partnership between the security and civil sectors while the 'new critics' called it a garrison state and emphasised its militaristic spirit. Sheffer and Barak (2013) have taken a new approach, which is to look at Israel's civil-security relationships as an informal network; a security network. For our purposes here, this approach is valuable as it emphasises the degree of the diffusion of former military personnel into the civil sphere, making the idea of different spheres an illusion.

Importantly, then, Israeli society and its state are highly militarised. Soldiers and (former) military commanders are omnipresent and strongly influential in the public sphere in which an idealisation of the fighting soldier is still evident. ${ }^{3}$ A military background is crucial to becoming successful in civilian life, while a combat background can grant especially men access to all kinds of work opportunities at home or abroad. Or, as Sara Helman (1997: 306) writes, the sustained participation of Israeli-Jewish males in the military rests upon its construction in terms of a community ... belonging to this community of warriors is experienced in terms of embeddedness in society, as a criterion of normalcy and as an entitlement that legitimises participation in the associations of civil society'. Notably, this military presence and subsequent ways of thinking are accepted and naturalised because they are seen as necessary and inevitable in conditions of structural insecurity. These processes of normalisation that entail 'modes of thought and action in which security considerations are pre-eminent' (Lomsky-Feder and Ben-Ari 1999: 6) have been characterised by Baruch Kimmerling (1993) as cognitive militarism.

Security and feelings of insecurity and fear are part of the negotiation of daily life, part of Israeli culture itself (Ochs 2011). When we try to find the reasons behind this entanglement of the prevalence of military and security issues, with feelings of fear and insecurity in Israeli society, we can of course look at the history of Israel and the wars the country has fought over the years. However, we should be careful not to reduce this preoccupation of Israel and its citizens solely to a 'real' and perhaps logical outcome of this history. As already noted, (in)security and feelings related to this concept are social constructs. This is not to say there is no insecurity in Israel and no real fear, but I emphasise here that the production of things or people as a threat is man-made (often by the state or military and/or security agents) and does not follow naturally from actual events. I contend that in the Israeli case the preoccupation with security is mostly a product of state efforts to engage people in the national Zionist quest. From early in life children are made aware of the risks of touching unidentified objects, everywhere in the streets one can spot security personnel and soldiers, and entry into shopping malls and bus and train stations is only possible after opening one's bags for inspection. This reverberates in the ideas of the 'few against many', the need of self-defence against many hostile neighbours, and 
in the post-World War II ideas of self-reliance when it comes to defending the nation - ideas the Israeli state has vocalised for decades.

Defending the nation is then foremost the official task of the military forces of Israel that have the meaningful name of the Israeli Defence Forces (IDF). While its name emphasises its defensive role, the IDF is also known for its aggressive operations against Palestinians in the West Bank and Gaza. Even so, these operations are framed by the Israeli establishment and by the press as defensive operations against the biggest threat of all: Palestinian terror. Israel has occupied the West Bank and Gaza since 1967. Neve Gordon (2008) argues that while Israel's occupation regime was first geared to the principle of colonisation, where land and people were controlled by the occupier, it later shifted to a principle of separation, which means that the occupied population comes under the control of its own people (the Palestinian Authority in this case), while space is still under the control of the occupier. This principle becomes very visible through the security or separation wall, with technological features such as cameras, heat sensors, and different kinds of fences, that Israel has been building since 2006 and the numerous checkpoints manned by Israeli soldiers and increasingly by private security personnel as well (Havkin 2014).

Israeli combat soldiers and commanders, then, have wide experience in the workings of this occupation. They stand at checkpoints and carry out patrols and nightly arrest operations (Grassiani 2013). They learn who should be perceived as the enemy, how the enemy should be 'destroyed' or 'neutralised', about intelligence and cyberattacks, and about how to prevent terrorist attacks. Thus during their service, they gain experience in urban combat, collecting intelligence, security technology, combat techniques, and more. With this background someone could pursue a professional military career, or sometimes a career in the secret services. After an early retirement (often around the age of forty-five), many choose to use their knowledge and skills in the military/security industry in the civil sphere.

The extensive experience from military service, and often a military or security career afterwards, thus becomes an important career asset for many Israeli men. ${ }^{4}$ Gordon (2009: 41) describes the way in which this typical Israeli experience plays a part in how the 'military and military industry have helped engender and develop Israel's homeland security sector'. This varies from specific know-how about security subjects, to combat experience in the military, to the right networks and ways of disseminating experience. Gordon (2009: 41-2) shows by outlining its different facets that ' $[\mathrm{t}]$ he power of Israeli experience derives from its multiple significations, the ability to create an artificial unity among them under the rubric of "Israeli experience", and to deploy them in order to manufacture and sell homeland security products'. Having a military background, the right contacts, and being situated in the right social and national context then becomes capital that can 
be marketed in order to sell goods and services. Importantly, the Israeli experience that is used to brand security goods on an international market is only part of the totality of Israel's military and covert activities in the Palestinian Territories. The suffering of the Palestinians under occupation is strategically left out of the picture (Gordon 2009).

The ISE brand is then closely connected to the Israeli state and its national brand; a state with a reputation of 'knowing security', or knowing terror and especially counter-terror. By emphasising this relationship with Israel, private companies can sell their products for a profit on the market. The direct relationship to the national brand of Israel begets them their unique selling point as sellers of high-quality security products.

\section{Israeli security abroad}

The reputation of Israel as a 'specialist' in security and counter-terrorism is ingeniously used by security professionals in order to sell their skills and experiences. Numerous Israelis have settled abroad and have founded security companies. They have thus actively exported their experiences and security knowledge. Some reveal their Israeli roots with pride, others are more cautious. Many Israeli security professionals I interviewed told me that while their Israeli-ness was very valuable from a business perspective, at times they had to downplay it 'because not everyone likes us', thereby pointing at critical positions some countries have towards Israel. In the following examples, I mostly focus on the way 'Israeli-ness' is used, but it is important to keep in mind it is sometimes actively hidden as well.

As mentioned above, the ISE brand blends in with the national brand of Israel. I first describe this brand further. ISE symbolises not only security and safety for its clients, but also specific values as know-how, toughness, morality, and a distinct kind of masculinity, all linked to Israel as the supposed number one in the security industry. Simultaneously, this experience, which is often gained through working as part of a military occupation or the security establishment, is infused with culturally constructed notions of safety and security. While there are numerous non-Israeli security companies using similar messages, I contend that the companies I analyse here use a distinct experience and narrative that relates to Israel as a nation state and to its history. This does not necessarily mean that these companies work in completely different ways from non-Israeli security companies, but they do use ISE to promote themselves as different from and more professional than their competitors.

Nation states increasingly try to brand themselves by identifying with a certain ideology or theme. Israel has a long history of explaining and showing to the world who/what it is. These efforts are called Hasbara, literally 'explaining', a means of uncritically rationalising Israel's position to the outside world. These efforts have been spurred by negative attention in the international press often 
related to Israel's military activities. But despite these negative reports and sentiments that have become louder in recent years, Israel still has succeeded in branding itself to the outside world as a country that is democratic, strong, a survivor, and superior in many industries, especially the security one.

Hasbara can thus be seen as a successful method to transport Israeli security capital across borders and Israeli-owned PSCs working outside Israel gladly use it. They emphasise Israel's elite security industry and its elite military consisting of the best soldiers. They use the combat and security experience and the national background of their founders and personnel as a brand. On one of the websites I analysed, the following quote is found: " $[w]$ e continue to truly and accurately represent the Israeli brand of security and counter-terrorist training' ${ }^{5}$ This makes it crystal clear that these businesses are in no way oblivious to this branding.

The data I collected comes from different sources. I analysed websites of different (mostly US) security companies, owned by Israelis or having some kind of other connection to Israel or ISE. Importantly, these companies use their Israeli connections explicitly when branding themselves. Furthermore, I use public relations material that I collected and received at security exhibitions and conferences in Israel or during interviews with security professionals there. I also use the interviews with security professionals that I conducted, not only in Israel, but also in Nairobi, Kenya.

ISE is central to the way these companies brand themselves. I show below how this brand is largely composed of the following elements: a great amount of know-how through first-hand experience in 'things security' ('being there'), toughness, masculinity, a moral way of working, and a profound knowledge of terrorism. Importantly, Israeli security has to be fitted and adjusted to a different context. This is mostly done by collapsing the terrorist threat with a criminal threat, thus showing how the same security methods can be used for both instances, something which is debatable.

\section{The brand}

As noticed before, for a brand to become a commodity, it needs to go through a process of qualification and requalification (Foster 2007). In the instance of ISE this has already been done, as Israel and its military have established a stable, positive aura around it. It is therefore ready to be branded, and a strong brand starts with a symbol. All companies I analyse here have understood this and the symbols they have chosen for their companies show a combination of (Israeli) national branding based on ISE. One US company's main symbol is an eagle with batwings in front of a triangle. The batwings are very similar to the symbol of the naval commando unit of the IDF, while the eagle is a known symbol for other units, but it is also used as the symbol for the US Navy Seals. The combination of 
the two makes it very similar to regular IDF insignia. As the company explains, this eagle with batwings behind it was chosen to symbolise strength, readiness, and superiority. ${ }^{6}$ Another US company, which was founded by an American Jew who joined the IDF and served in a special combat unit, portrays a shooter with a handgun, above him a text in Hebrew which says 'Counter Terror School'.? Beneath the shooting figure we find the English translation. A third US company also gives away the desire to communicate a strong connection to Israel; within a shield we see the American flag and the statue of Liberty, but on the forefront of these two American symbols we see a sword and an olive branch within the outlines of the Star of David, the symbol of the IDF. And finally, a South Africanbased company uses the symbol of the Golani brigade, a green tree with a yellow background that is recognisable to most Israelis as symbolising this infantry combat unit, and, most importantly, its name to show its close affiliation with that IDF unit in which the Israeli founder served. Symbols are important when sending a message about a company's goal and worldview and the Israeli connection is often part of it.

If we continue the story of the brand, Israeli know-how seems to be central to it. All companies of Israelis abroad mention the experience of their operatives in the Israeli military and secret services, and the Israeli security professionals I spoke to emphasised time and again how their Israeli (military and security) background was crucial for their business. Israeli military know-how seems to be taken for granted and is not explicitly explained, however. When I asked security professionals what it was that made this experience and background so specific they would not have an answer ready, and would mostly say to me (as a fellow Israeli) 'you know'. The assumption was that only mentioning it was enough. As one Israeli security professional who was based in Los Angeles told me: ' $[\mathrm{t}]$ he Israeli security concept is the brand ... [W]e have no need for marketing, the results speak for themselves'. Implicitly (and at times explicitly), the link is made with Israel's rich experience of wars and terror and of its highly developed military industry.

In the testimonials of custumers of Israeli-manned security companies, this is mentioned several times; a member of a Houston Special Weapons and Tactics (SWAT) team wrote on one website: '[w] hat he [the instructor] brought to us was an expertise that could only be learned by one who has been there'. ${ }^{8}$ The first sentence under the heading 'About Us' on the website of another US company reads as follows: '[i]n December 2001, Rami Hahitti, founded Security USA, Inc. a protective services company based on the principles he learned in the Israeli Defence Forces'. ${ }^{9}$ Such statements can be found on many companies' websites, emphasising the connection to the Israeli military and the experiences the founders and/or operatives had there. The website of Security USA furthermore states that 'the Israeli security experience proves that when security issues are dealt with as a top priority, damage is greatly mitigated and people 
feel less threatened. Reaching this state of readiness requires knowledge, practical training, simulation of unusual situations and mental toughness'. ${ }^{10}$ Again, superior security knowledge is directly related to ISE. In explaining 'who they are', one company reveals its Israeli roots, as it claims to merge American and Israeli 'know how' into its services. ${ }^{11}$ Another company based in Israel writes in its folder that their 'human factor which is manifested both in our security concepts, plans and also in our consultants and personnel, all former operatives of the Israeli Security Agency, Mossad and Defense forces' is the reason for its success. $^{12}$

One company, IMS, was founded by Aaron Cohen, a Jewish US citizen who served in the IDF. In all interviews and news items in which Cohen or his company are mentioned, his experience as former operative in an Israeli elite combat unit is explicitly stated (when Cohen spoke during an interview with Larry King, his identity was shown on screen as 'former Israeli Special Forces Operative'). ${ }^{13}$ Thus this explicit connection to Israel and its military and/or security operations serves as a unique selling point for all these security companies. The fact that the operatives of the companies have experienced conflict, danger, and terror themselves as former Israeli combatants is an important part of their security capital, which is converted to symbolic capital on the international security market.

A second facet of the Israeli security brand is the emphasis on Israeli masculinity. Israeli combat soldiers and security professionals are almost solely men. The companies they set up abroad are also often entirely staffed by male operatives. While most PSCs emphasise their masculinity, I want to stress the distinct Israeli characteristics that are used by these PSCs. Israeli masculinity is in many ways closely connected to military experience and thus militarised. Early Zionist framing of the perfect new Israeli citizen or the 'New Jew' depicted him as the opposite of the ghetto Jew, who was seen as weak and even feminine (Wistrich 1995). Theodor Herzl, modern Zionism's founding father, was especially clear on this. His Zionism meant the forging of 'a noble ideal of a new Jew, a man living by the myth of chivalry, who will be the anti-thesis of the old ghetto culture' (Wistrich 1995: 15). The New Jew was a man who was depicted as the ideal soldier, defending his new land. The new generations of children, born in what was to become Israel were named 'Sabras' after the cactus fruit, as they were to be soft and friendly on the inside but tough on the outside (Almog 2000). Emphasis was laid on the fighting spirit of the new ideal Israeli, with clearly militarised masculine characteristics. These characteristics can be traced back to the brand I analyse here.

Cohen's personal story that features prominently on the IMS website fits right in with this concept of masculinity; the story is told of a young American who leaves his comfortable home behind to fight in a secret elite IDF unit, thus becoming the ideal Jewish Israeli man. Another feature of this distinct masculinity is an Israeli 'way of doing things' that was often mentioned to me in interviews. 
This efficient, loyal, no-nonsense way of getting a job done is very much connected to the above-mentioned Zionist masculine figure that is a hard worker and loyal to the bone. Israeli soldiers are expected to comply with these codes of masculinity (Ben-Ari 1998). One employee of an Israeli company working in Nairobi told me, for instance, that it was the real caring (ekhpatiut) by the company for its customers and the company's efficiency that made the way in which he and his (male-only) team worked typically Israeli.

This way of working also features as part of the third element i discuss here; the companies' morality that is emphasised as part of the ISE brand. One company stresses its own code of ethics, which is almost literally copied from the official IDF code, albeit altered to be used in the public sphere and outside Israel. It even calls its code the 'Spirit of ISI' (ISI being the name of the company); the code of ethics of the IDF is called the 'Spirit of the IDF'. This latter code requires Israeli soldiers to uphold a high moral standard. Values mentioned in this code are, for example, comradeship, purity of arms (which means one can only use a weapon in defensive action), and discipline. Many of my informants also mentioned the work ethic as something specific to the 'Israeli-ness' of their companies. One informant told me how he and his colleagues when working in Gabon were able to complete their work within three months as they were very disciplined (dvikut bamesima), a Hebrew concept coming directly from the IDF code of ethics.

A fourth and final element of the ISE brand is knowledge of terrorism and terrorists. Most security professionals I spoke to and the companies I studied boast a deep knowledge of what terror is and most of all what the best ways are to combat it. These skills are taught to other (foreign) parties, such as SWAT teams or military units, during counter-terror trainings. Security professionals seem to take the relationship between being a former Israeli combatant or member of the Israeli Security Agency (ISA) and knowing more than average about Islam and terrorism as completely natural. The knowledge about terror and most of all the definition of what terrorism entails is presumed because of the experience of Israelis in a conflict involving Muslims (the Palestinians in this case) and terror attacks. It is thus seen as a given that their extensive experience with terror makes them experts, as can be read on one website: '[terrorism] seminars are taught by Israeli anti-terrorist professionals with extensive knowledge and years of hands-on field experience dealing with terrorism' ${ }^{14}$ Another company boasts that '[o]ur Israeli-trained security team can provide a proper on-site vulnerability assessment with expertise in specifically dealing with post 9/11 style terrorism attacks involving the use of explosives as well as active shooter type incidences that are focused at targeting mass crowds'. ${ }^{15}$ During a security seminar I joined in Israel that was directed at different kinds of customers from all over the world, one afternoon was dedicated to a lecture on 'international and national terror threats', with a focus on the threat of Islam and Islamic terror. It is thus assumed that ISE also consists of correct or even objective knowledge 
about Islam and the assumed threats it poses. However, the knowledge that is provided is very one-sided, if not to say racist and generalising.

\section{Notions of security and terrorism: adapting to foreign clients' needs}

In the exploration of the ISE brand above, I emphasised the central elements of this brand that connected it to Israel as a state with a profound security background. However, it is important to acknowledge that these companies not only export and use the reputation of Israeli combatants and other security specialists, they also utilise culturally constructed notions of what security and terrorism is. Coming from a highly militarised society and having experienced and participated in a military occupation, the operatives of these companies are overly familiar with security concepts and their meanings are natural to them. Such notions are constructs, they are products of a specific socialisation within which security issues are perceived to be central to society's very being. When Israeli security agents go to work abroad, they not only export technologies and materials, they most of all bring with them specific ideas about what security and hostility mean, who should be perceived as the enemy, and what the best ways are to combat this hostile 'other'. However, in order for this mobility to be successful, the ISE brand must be tuned to the new context. I show below how this is done by categorising threats and spaces in such a way that military and antiterror techniques from the military occupation of the Palestinian Territories can be used in the streets of New York or Los Angeles.

In the case of IMS, counter-terror and operations against stalkers of celebrities in Hollywood are put on the same page. While most people know IMS founder Cohen for his work with celebrities, the company website also emphasises counter-terror training and techniques. A direct connection is made between the protection of celebrities and the fight against terror, in which Israeli ex-soldiers are expected to specialise. Cohen was quoted as saying that giving Britney Spears subpoenas was ‘pure counter-terrorism’ (Spence 2007: n.p.). He added that tracking down Spears 'required the same tactics as tracking a terrorist' (Spence 2007: n.p.).

ISI boasts on its website about the operation mentioned in the introduction of this chapter by stating that

[i]n the aftermath of Hurricane Katrina, ISI was called upon to protect private assets. Within 24 hours, an ISI team was assembled and dropped by helicopter into the disaster zone and operated in the hostile environment for 60 days with no incidents or incursions. ${ }^{16}$

ISI's choice of words is interesting; while it was true there had been looting and a sphere of insecurity in New Orleans straight after the hurricane, to call the specific surroundings of Audubon Place a hostile environment is something 
else. It is an effort to collapse images of war and conflict and those of criminality in a civilian, urban context into each other. And once a situation is identified as hostile and dangerous, it is not surprising to find military means being used to protect citizens. This militarisation of urban space can increasingly be seen in the US, but also in Europe. Stephen Graham (2011: xiv) calls this a 'new military urbanism', including 'militarized techniques of tracking and targeting' people within the city. Furthermore, it entails that the civilian population regards this militarisation as natural.

Besides blurring the lines between terror, war, and criminality, the 'enemy' also becomes a generic figure. When speaking about terror and while clearly connecting oneself to Israel and the Israeli military as Cohen does, the 'other' easily becomes associated with the Palestinian or the Muslim in general. This can be seen in a promotional film for IMS, in which Cohen performs a mock training exercise. He dresses up as 'the enemy' in order to surprise his trainees and see if they know how to react. He dresses himself as an Arab, wearing a kafiya scarf (a traditional Arab headdress, mostly worn by men and increasingly seen as a symbol of the Palestinian struggle for independence) and a beard. The 'other' in this case is clearly the Muslim 'other', a terrorist. As such the idea of who is the enemy is directly imported from the occupied Palestinian Territories into the Hollywood Hills.

As mentioned before, terrorism seminars given by Israeli security professionals are often exclusively about Islamic terror, or in the words of one company 'global Jihad radical Islamic Terrorism'. ${ }^{17}$ Not only is the history of terror groups assumed to be taught, but solutions are also offered on the foreign market, thus emphasising that Israelis know very well how to deal with this common enemy. By collapsing different categories of threat (terrorism and criminality), as well as turning civilian spaces into hostile (war) zones, security companies using the ISE brand fine-tune their methods and ideologies to use them within different contexts.

\section{Conclusion}

This chapter has shown the ways in which Israeli security and military experience has become security capital and subsequently a brand that is used to sell security products and ideas on an international market. Israeli security personnel, security knowledge, and technologies are very popular in times where everyone seems to believe we are under constant threat. Ideas about (in)security and risk are not only used by PSCs to sell their goods, but they are also created by these companies who portray themselves as security specialists, able to advise on risks.

By analysing companies that each in its own way identifies heavily with Israeli security and military experience, I defined a more general ISE brand. This 
brand first of all consists of symbols related to Israel and the IDF. Furthermore, it contains the value of 'Israeli know-how' and a Zionist masculinity. Moreover, a specific kind of morality and work ethic is propagated by the brand, and finally the naturalisation between a background as an Israeli combatant and extensive knowledge of terrorism was identified. Importantly, I also showed how these companies try to fit this brand neatly into different contexts. By using categories of war and conflict within urban areas, and collapsing terror with criminality, military methods and technologies can be uncritically used within a civilian sphere.

I have looked at the larger military/security industrial complex through which Israel connects to the world beyond its borders by examining this connection on a small scale. By expanding the concept of branding from products and places to experiences and security experiences in particular, we can explore such efforts and understand more closely how culturally constructed concepts, technologies, and ideologies migrate from place to place within the larger context of military/security networks.

\section{Notes}

1 Presentation at the American Anthropological Association in New Orleans in 2010.

2 The PCSs are mostly not Israeli as such, because they are not registered in Israel, but they all have a distinct Israeli connection, often through the founders who are almost exclusively Israeli. PSCs are not new to our times and have existed in their current, businesslike form since the end of the Cold War (Singer 2011). They can be seen as part of the growing privatisation of state tasks and responsibilities to the private public and private companies.

3 Israel has compulsory conscription; men are called up for three years, women for twentyfour months. All Palestinians living within Israel except for the Druze community are exempted from this conscription. Jewish Orthodox men and women usually do not serve, even though an elaborate debate on the subject takes place in Israel and efforts have been made to draft new laws on the subject.

4 While there are increasing numbers of women joining the ranks of combat soldiers, the great majority are still men. Also the (symbolic) rewards of this service are reserved for men only.

5 http://web.archive.org/web/20160303195509/http://www.ims-security.com/ (accessed 15 July 2016).

6 http://isitrainingcenter.com (accessed September 2014).

7 http://web.archive.org/web/20160120194836/http://ims-security.com/airport_security.htm (accessed 15 July 2016).

8 http://web.archive.org/web/20160310013452/http://www.ims-security.com/testimonials.htm (accessed 15 July 2016).

9 www.securityusa.info/Company/CompanyProfile (accessed November 2014).

10 www.securityusa.info/Company/CompanyProfile (accessed November 2014). The use of the concept of ISE by the company is a 'fruitful' coincidence. My terminology does not stem from it, but it is telling that a security company mentions it so explicitly.

11 www.isitrainingcenter.com (accessed September 2014). 
12 ISDS folder.

13 www.youtube.com/watch? $v=$ cysjcS-e1N4 (accessed October 2015).

14 http://web.archive.org/web/20141003232640/http://www.isitrainingcenter.com/ terrorism-seminars.html (accessed 15 July 2016).

15 http://web.archive.org/web/20160106200028/http://www.ims-security.com/counter\%20terrorist $\% 20$ security\%20large $\% 20$ events.htm (accessed 15 July 2016).

16 http://web.archive.org/web/20150213092805/http://www.isitrainingcenter.com/ global-services.html (accessed 15 July 2016).

17 www.isitrainingcenter.com (accessed September 2014).

\section{REFERENCES}

Almog, O., 2000. The Sabra: The Creation of the New Jew, Berkeley, CA: University of California Press.

Ben-Ari, E., 1998. Mastering Soldiers, New York: Berghahn.

Bourdieu, P., 2002. 'The Forms of Capital', in N. Biggart, ed., Readings in Economic Sociology, Oxford: Blackwell.

Buzan, B., O. Wæver, and J. De Wilde, 1998. Security: A New Framework for Analysis, Boulder, CO: Rienner.

Coaffee, J. and P. Rogers, 2008. 'Reputational Risk and Resiliency: The Branding of Security in Place-making', Place Branding and Public Diplomacy 4(3): 205-17.

Coaffee, J. and P. Van Ham, 2008. "Security Branding”: The Role of Security in Marketing the City, Region or State', Place Branding and Public Diplomacy 4(3): 191-5.

Foster, R. J., 2007. 'The Work of the New Economy: Consumers, Brands, and Value Creation', Cultural Anthropology 22(4): 707-31.

Furedi, F., 2002. Culture of Fear, New York: Continuum.

Furedi, F., 2006. Culture of Fear Revisited, London: Bloomsbury Publishing.

Goldstein, D. M., 2010. 'Toward a Critical Anthropology of Security', Current Anthropology 51(4): 487-517.

Goold, B., I. Loader, and A. Thumala, 2010. 'Consuming Security? Tools for a Sociology of Security Consumption', Theoretical Criminology 14(1): 3-30.

Gordon, N., 2008. 'From Colonization to Separation: Exploring the Structure of Israel's Occupation', Third World Quarterly 29(1): 25-44.

Gordon, N., 2009. The Political Economy of Israel's Homeland Security/Surveillance Industry. Surveillance Studies Centre, Queen's University, The New Transparency Project. Working Paper III. Available at www.sscqueens.org/sites/default/files/The\%20 Political\%20Economy\%20of\%20Israel\%E2\%80\%99s\%20Homeland\%20Security. pdf (accessed 15 July 2016).

Graham, S., 2011. Cities under Siege: The New Military Urbanism, London: Verso Books.

Grassiani, E., 2013. Soldiering under Occupation: Processes of Numbing among Israeli Soldiers in the Al-Aqsa Intifada, New York: Berghahn Books.

Havkin, S., 2014. 'The Reform of Israeli checkpoints: Outsourcing, Commodification, and Redeployment of the State'. Report for the Centre d'Etudes et de Recherche Internationales, Les Etudes tu Ceri. 
Helman, S., 1997. 'Militarism and the Construction of Community', Journal of Political and Military Sociology 25(2): 305.

Hutchinson, G. and T. Masson, 2007. The Great New Orleans Gun Grab: Descent into Anarchy, Boutte, LA: Louisiana Publishing.

Joachim, J. and A. Schneiker, 2014. 'All for One and One in All: Private Military Security Companies as Soldiers, Business Managers and Humanitarians', Cambridge Review of International Affairs 27(2): 246-67.

Johnson, J., 2010. 'When Only the Best Will Do, Hire an Israeli Commando'. Available at http://vanityfair.com/online/daily/2010/06/when-only-the-best-will-do-hire-anisraeli-commando (accessed 30 October 2015).

Kavaratzis, M. and G. J. Ashworth, 2005. 'City Branding: An Effective Assertion of Identity or a Transitory Marketing Trick?', Tijdschrift voor economische en sociale geografie 96(5): 506.

Kimmerling, B., 1993. 'Patterns of Militarism in Israel', European Journal of Sociology 34(2): 196-223.

Krahmann, E., 2008. 'Security: Collective Good or Commodity?', European Journal of International Relations 14(3): 379-404.

Leander, A., 2005. 'The Market for Force and Public Security: The Destabilizing Consequences of Private Military Companies', Journal of Peace Research 42(5): 605-22.

Loader, I., 1999. 'Consumer Culture and the Commodification of Policing and Security', Sociology 33(2): 373-92.

Lomsky-Feder, E. and E. Ben-Ari, eds, 1999. The Military and Militarism in Israeli Society, New York: SUNY Press.

Mythen, G. and S. Walklate, 2006. 'Communicating the Terrorist Risk: Harnessing a Culture of Fear?', Crime, Media, Culture 2(2): 123-42.

Neocleous, M., 2007. 'Security, Commodity, Fetishism', Critique 35(3): 339-55.

Ochs, J., 2011. Security and Suspicion: An Ethnography of Everyday Life in Israel, Philadelphia, PA: University of Pennsylvania Press.

Pine, B. J. and J. H. Gilmore, 1998. 'Welcome to the Experience Economy', Harvard Business Review 76: 97-105.

Scahill, J., 2005. 'Blackwater Down', The Nation 21.

Sheffer, G. and O. Barak, 2013. Israel's Security Networks: A Theoretical and Comparative Perspective, Cambridge: Cambridge University Press.

Singer, P. W., 2011. Corporate Warriors: The Rise of the Privatized Military Industry, Ithaca, NY: Cornell University Press.

Spence, R., 2007. 'Paparazzi, Beware! Hollywood Stars Have a Secret Weapon: Israeli Commandos'. Available at http://forward.com/news/11884/paparazzi-bewarehollywood-stars-have-a-secret-w-00686/ (accessed 30 October 2015).

Van Ham, P., 2001. 'The Rise of the Brand State: The Postmodern Politics of Image and Reputation', Foreign Affairs 80(5): 2-6.

Wistrich, R. S., 1995. 'Theodor Herzl: Zionist Icon, Myth-Maker and Social Utopian', Israel Affairs 1(3): 1-37. 